\title{
IN VIVO ACTIVITY OF CEFBUPERAZONE (T-1982) AGAINST VARIOUS EXPERIMENTAL INFECTIONS IN MICE
}

\author{
Isamu Suzuki* and Hisato Senda \\ Tokyo Research Laboratories, Kaken Pharmaceutical Co., Ltd., \\ 2-28-8 Honkomagome, Bunkyo-ku, Tokyo 113, Japan \\ TAKESHI YOKOTA \\ Department of Bacteriology, School of Medicine, Juntendo University, \\ 2-1-1 Hongo, Bunkyo-ku, Tokyo 113, Japan \\ (Received for publication September 20, 1984)
}

\begin{abstract}
The protective activity of cefbuperazone (T-1982) was compared with those of latamoxef, cefotaxime, and cefmetazole against intraperitoneal and urinary tract infections in mice. In both tests, cefbuperazone manifested a higher activity than the other cephems against infections with Escherichia coli and Klebsiella pneumoniae. Cefbuperazone also showed a comparatively high degree of prophylactic effect; this activity was observed even when given 4 hours before bacterial challenge. The good in vivo activity of cefbuperazone could not be explained by the differences between the antibiotics on the basis of the serum levels and in vitro activity. Mice, treated with cefbuperazone, showed a statistically significant prolongation of survival time against intraperitoneal challenge with Candida albicans, but not when treated with the other cephems. This finding suggests that the host defense mechanisms stimulated by cefbuperazone may contribute to the good in vivo activity of this antibiotic.
\end{abstract}

Cefbuperazone (T-1982) is a new semisynthetic cephamycin antibiotic with a broad spectrum of antibacterial activity against Gram-positive and Gram-negative bacteria, including Bacteroides fragili $^{1,2)}$, and is highly resistant to hydrolysis by various types of $\beta$-lactamases ${ }^{1,2,3)}$. In vivo, cefbuperazone is especially more active than other cephems against various species of Enterobacteriaceae ${ }^{1,2}$. Cefbuperazone was shown to have a marked synergy with the bactericidal effect of serum complement and macrophages ${ }^{4}$. This synergistic action is considered as reason for the comparatively high in vivo activity of the antibiotic.

Because of the better efficacy of cefbuperazone over other cephems, further studies were done to evaluate the activity of this new antibiotic in vivo against intraperitoneal and urinary tract infections in mice. In addition, studies were done to determine whether cefbuperazone can increase the host defense mechanisms of mice against experimental Candida albicans infection.

The present paper deals with these results in comparison with latamoxef, cefotaxime, and cefmetazole.

\section{Materials and Methods}

Antibiotics

Cefbuperazone was synthesized in the Tokyo Research Laboratories of Kaken Pharmaceutical Co., Ltd. Latamoxef was purchased from Shionogi \& Co., Ltd., Osaka, cefotaxime from Hoechst Japan Limited, Tokyo, cefmetazole from Sankyo Co., Ltd., Tokyo. Each antibiotic was dissolved in $0.85 \%$ saline just before use. In most experiments, antibiotics were administered subcutaneously to 
mice in $0.2 \mathrm{ml}$ doses.

Microorganisms

Escherichia coli $\mathrm{KC}-14$ and Klebsiella pneumoniae KC-1 were donated by Dr. T. NisHino of the Kyoto College of Pharmacy, Kyoto and E. coli ML4707 by Dr. S. MitsuHASH of Gunma University, Maebashi. Candida albicans was originally isolated from clinical material.

Mice

Four weeks old JCL: ICR mice (Clea Japan Inc., Tokyo), weighing $19 \pm 1$ g, were used. Each experimental group consisted of 10 male mice for intraperitoneal infections, and 5 female mice for urinary tract infections. Serum levels of antibiotics were measured using 5 male mice per group.

Determination of MICs and MBCs

MICs were determined by the standard serial 2-fold dilution method, using Mueller-Hinton agar (Nissui Pharamceutical Co., Ltd., Tokyo). An overnight culture in Mueller-Hinton broth (Nissui) was diluted with the same medium to a cell concentration of $10^{6}$ colony forming units (cfu) per $\mathrm{ml}$ for inoculation. The MICs were determined after incubation at $37^{\circ} \mathrm{C}$ for 20 hours. The tests with $C$. albicans were performed on Sabouraud agar (Nissui), inoculated with the suspension containing $10^{8}$ $\mathrm{cfu} / \mathrm{ml}$ from the overnight culture in Sabouraud broth at $30^{\circ} \mathrm{C}$, followed by incubation at $30^{\circ} \mathrm{C}$ for 20 hours.

MBCs (Minimum bactericidal concentrations) and MICs were determined by the broth dilution method, using Mueller-Hinton broth and bacterial inocula of $10^{4} \mathrm{cfu} / \mathrm{ml}$. The MIC in broth was defined as the lowest concentration of antibiotic showing no turbidity after incubation at $37^{\circ} \mathrm{C}$ for 20 hours. To determine the MBCs, subcultures were made on antibiotic-free agar plates from each clear tube in the MIC test series, followed by incubation at $37^{\circ} \mathrm{C}$ for 20 hours.

Measurement of Serum Levels

Each antibiotic was injected subcutaneously to normal mice with 1 or $4 \mathrm{mg} / \mathrm{mouse}$ in a single dose. The mice were sacrificed by decapitation at different intervals after the injection, and blood samples were collected from the carotid artery. Concentrations of antibiotics in the sera were determined by an agar disk diffusion microbioassay, using K. pneumoniae ATCC 10031 for cef buperazone, E. coli NIHJ for latamoxef, and Micrococcus luteus ATCC 9341 for cefotaxime and cefmetazole. In the assay, the pooled serum of normal mice was used for dilution of the samples. Concentrations of antibiotics were calculated from the standard curves. The assay sensitivities were 0.39 for cefbuperazone, 1.56 for latamoxef, 0.2 for cefotaxime, and $0.78 \mu \mathrm{g} / \mathrm{ml}$ for cefmetazole, respectively.

Protection Tests against Intraperitoneal and Urinary Tract Infections in Mice

Test organisms were cultured in nutrient broth (Nissui) at $37^{\circ} \mathrm{C}$ for 16 hours with shaking. Mice were intraperitoneally injected with $0.5 \mathrm{ml}$ of a bacterial suspension in saline or in $3 \%$ gastric mucin (Wako Chemical Co., Ltd., Osaka). Inoculum sizes ranged from 10 to 50 times the minimal lethal dose. In every experiment, all untreated mice died within 3 days after infection. Antibiotics were administered subcutaneously once at different times before or after infection. $\mathbf{E D}_{50}$ values were calculated by the Litchfield-Wilcoxon method from survival rates 7 days after infection.

For urinary tract infections ${ }^{5)}$, mice were prevented from drinking water for 20 hours before bacterial challenge. A bacterial suspension in $0.1 \mathrm{ml}$ of nutrient broth was given transurethrally to the mice anesthetized intraperitoneally with $1 \mathrm{mg}$ /mouse of sodium pentobarbital (Dainippon Pharmaceutical Co., Ltd., Osaka). The external urethral meatus was clamped for 4 hours after infection. Antibiotics were administered subcutaneously once 4 hours after challenge with $E$. coli $\mathrm{KC}-14$, and three times at 4, 24 and 29 hours with $K$. pneumoniae $\mathrm{KC}-1$. Bacterial cells in the kidneys were counted to evaluate the therapeutic effects of antibiotics as follows. The mice were sacrificed 24 hours after infection with $E$. coli and 48 hours with $K$. pneumoniae. A pair of kidneys was removed aseptically and homogenized in $5 \mathrm{ml}$ of saline. Serial 10-fold dilutions of the homogenates were prepared with saline, and $1 \mathrm{ml}$ of each sample was mixed with melted nutrient agar, followed by incubation at $37^{\circ} \mathrm{C}$ for 20 hours. 
Table 1. Protective activity of cefbuperazone against intraperitoneal infections in mice.

\begin{tabular}{|c|c|c|c|c|c|c|c|}
\hline Organism & $\underset{3 \%}{\text { Mucin }}$ & $\begin{array}{c}\text { Challenge } \\
\text { dose } \\
\text { (cfu/mouse) }\end{array}$ & Antibiotic & $\begin{array}{c}\mathrm{MIC} \\
(\mu \mathrm{g} / \mathrm{ml})\end{array}$ & $\begin{array}{c}\mathrm{ED}_{50} \\
\text { (mg/mouse) }\end{array}$ & $\begin{array}{l}95 \% \\
(\mathrm{mg}\end{array}$ & $\begin{array}{l}\text { confidence } \\
\text { limit } \\
\text { /mouse) }\end{array}$ \\
\hline \multirow{8}{*}{$\begin{array}{l}\text { Escherichia coli } \\
\text { KC-14 }\end{array}$} & \multirow[t]{4}{*}{+} & \multirow[t]{4}{*}{$8.7 \times 10^{4}$} & Cefbuperazone & 0.05 & 0.00075 & \multicolumn{2}{|c|}{$0.00058 \sim 0.00098$} \\
\hline & & & Latamoxef & 0.025 & 0.0015 & \multicolumn{2}{|c|}{$0.0011 \sim 0.002$} \\
\hline & & & Cefotaxime & 0.025 & 0.00058 & \multicolumn{2}{|c|}{$0.00045 \sim 0.00075$} \\
\hline & & & Cefmetazole & 0.2 & 0.023 & 0.015 & $\sim 0.035$ \\
\hline & \multirow[t]{4}{*}{-} & \multirow[t]{4}{*}{$1.0 \times 10^{?}$} & Cefbuperazone & & 0.025 & 0.018 & $\sim 0.034$ \\
\hline & & & Latamoxef & & 0.085 & 0.065 & $\sim 0.11$ \\
\hline & & & Cefotaxime & & 0.13 & 0.018 & $\sim 0.21$ \\
\hline & & & Cefmetazole & & 0.6 & 0.42 & $\sim 0.85$ \\
\hline \multirow{8}{*}{$\begin{array}{l}\text { Klebsiella } \\
\text { pneumoniae } \\
\text { KC-1 }\end{array}$} & \multirow[t]{4}{*}{+} & \multirow[t]{4}{*}{$3.9 \times 10^{3}$} & Cefbuperazone & 0.1 & 0.14 & 0.093 & $\sim 0.21$ \\
\hline & & & Latamoxef & 0.1 & 0.34 & 0.2 & $\sim 0.54$ \\
\hline & & & Cefotaxime & 0.05 & 0.15 & 0.1 & $\sim 0.22$ \\
\hline & & & Cefmetazole & 0.78 & 1.3 & 0.8 & $\sim 2.1$ \\
\hline & \multirow[t]{4}{*}{-} & \multirow[t]{4}{*}{$3.9 \times 10^{3}$} & Cefbuperazone & & 0.18 & 0.15 & $\sim 0.21$ \\
\hline & & & Latamoxef & & 0.64 & 0.47 & $\sim 0.86$ \\
\hline & & & Cefotaxime & & 0.34 & 0.25 & $\sim 0.48$ \\
\hline & & & Cefmetazole & & 1.4 & 0.93 & $\sim 2.1$ \\
\hline
\end{tabular}

Mice: ICR, $19 \pm 1 \mathrm{~g}, 10$ animals/group.

Infection (ip): $0.5 \mathrm{ml}$ of a bacterial suspension in $3 \%$ mucin or in saline.

Therapy (sc): Once at 1 hour after infection.

MIC: With a bacterial suspension of $10^{3} \mathrm{cfu} / \mathrm{ml}$.

$\mathrm{ED}_{50}$ : By the Litchfield-Wilcoxon method.

Effect of Cefbuperazone on Experimental C. albicans Infection in Mice

An overnight culture of C. albicans in Sabouraud broth at $30^{\circ} \mathrm{C}$ was streaked on Sabouraud agar plates, followed by incubation at $30^{\circ} \mathrm{C}$ for 20 hours. The cells of $C$. albicans were harvested, washed twice and resuspended in saline. Mice were intraperitoneally infected with $0.5 \mathrm{ml}$ of the suspension. The mice were subcutaneously treated with various amounts of each antibiotic in a single dose 4 hours before, immediately after, and 1 hour after the infection. The survival numbers of the saline-treated control and antibiotic-treated groups were recorded every day. The experiment was terminated on day 7 after infection. The survival curve of each treatment group was statistically compared with that of the control group. $P$ values were based on the Cox-Mantel test.

\section{Results}

Protective Activity of Cefbuperazone against Intraperitoneal Infections

Table 1 shows the protective activities of cefbuperazone and the reference antibiotics against intraperitoneal infections.

Each antibiotic was administered 1 hour after infection. Against the infection with E. coli $\mathrm{KC}-14$ suspended in mucin, the $\mathrm{ED}_{50}$ of cefbuperazone was lower than those of latamoxef and cefmetazole, and almost the same as that of cefotaxime. Against the infection without mucin (in saline), cefbuperazone was more active than the other antibiotics. The MIC of cefbuperazone for this strain was two times higher than those of latamoxef and cefotaxime.

Similar results were obtained with cefbuperazone in protection against $K$. pneumoniae $\mathrm{KC}-1$, although the MIC of this antibiotic to the organism was equal to that of latamoxef and two times higher than that of cefotaxime. 
Fig. 1. Protective activity of cefbuperazone against urinary tract infections.

Mice (19 $\pm 1 \mathrm{~g}, 5$ animals/group) were transurethrally infected with test organisms in $0.1 \mathrm{ml}$ of medium. The bacterial numbers in a pair of the kidneys were counted 24 hours after infection with E. coli $\mathrm{KC}-14$, and 48 hours with $K$. pneumoniae $\mathrm{KC}-1$. Each value represents mean $\pm \mathrm{SD}$.

(A) E. coli $\mathrm{KC}-14$.

Inoculum size: $1.0 \times 10^{5} \mathrm{cfu} /$ mouse.

Therapy (sc): Once at 4 hours after infection.
(B) $K$. pneumoniae $\mathrm{KC}-1$.

Inoculum size: $2.0 \times 10^{5} \mathrm{cfu} / \mathrm{mouse}$.

Therapy (sc): Three times at 4, 24, 29 hours after infection.
(A)

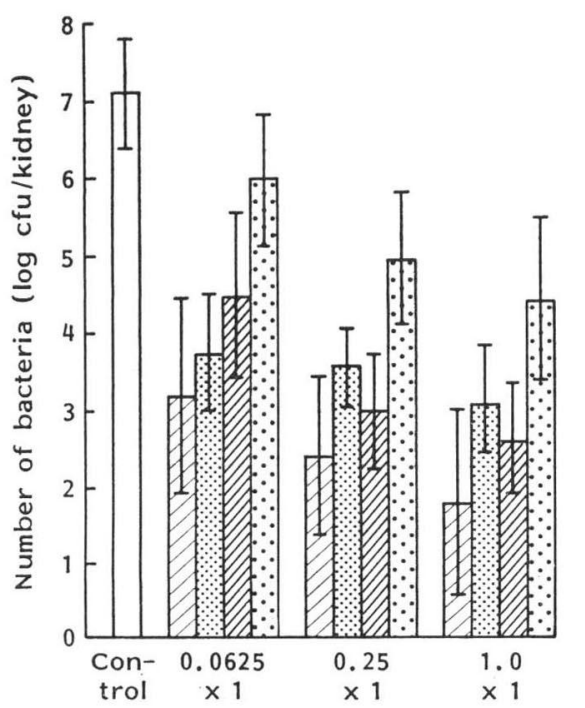

(B)

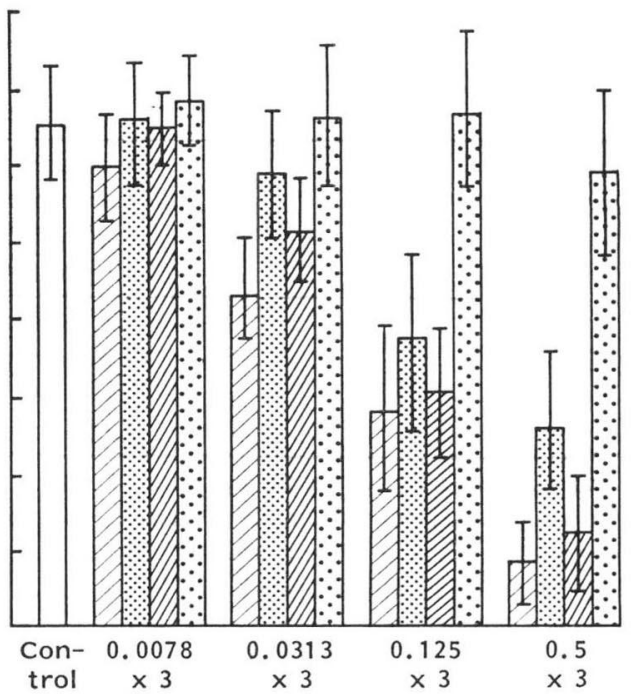

Dose $(\mathrm{mg} / \mathrm{mouse}) \times$ times of dosing

Cefbuperazone, ${ }^{3}$ Latamoxef, $\square$ Cefotaxime, $\because$ Cefmetazole

\section{Protective Activity of Cefbuperazone against Urinary Tract Infections}

As shown in Fig. 1A, the bacterial numbers in the kidneys of cefbuperazone-treated mice were compared with those of the control and other antibiotic-treated mice 24 hours after infection with E. coli $\mathrm{KC}-14$.

The bacterial numbers increased to $10^{7.13} \mathrm{cfu} /$ kidney in the control group. The decrease of bacterial numbers in the kidneys at every dose level was more marked in cefbuperazone-treated groups than in groups treated with the other antibiotics.

In the tests with $K$. pneumoniae $\mathrm{KC}-1$, similar results were obtained in the cefbuperazone-treated groups 48 hours after the infection (Fig. 1B).

\section{Effect of a Single Dose of Cefbuperazone on Intraperitoneal Infections When Administered Before or After Bacterial Challenge}

The antibiotics were administered in a single dose of $0.125 \mathrm{mg} / \mathrm{mouse}(0.5 \mathrm{mg} / \mathrm{mouse}$ for cefmetazole) to mice at different times before or after the infection with E. coli $\mathrm{KC}-14$.

As shown in Fig. 2, the survival numbers of cefbuperazone-treated mice on 7 days after the infection were higher than those of mice treated with the other antibiotics even when the antibiotics were administered 1 hour before the infection.

As shown in Fig. 3, the protective effect of cefbuperazone was further confirmed for the bacterial infections with $E$. coli $\mathrm{KC}-14, E$. coli ML4707 and $K$. pneumoniae KC-1. ED $_{50}$ s of cefbuperazone were 
Fig. 2. Protective activity of cefbuperazone against intraperitoneal infection when administered before or after bacterial challenge.

Mice (19 $\pm 1 \mathrm{~g}, 10$ animals/group) were infected with $8.0 \times 10^{8} \mathrm{cfu} / \mathrm{mouse}$ of $E$. coli $\mathrm{KC}$-14 suspended in $0.5 \mathrm{ml}$ of saline. The antibiotics were administered subcutaneously once at the times indicated in the figure.

Dose: $0.125 \mathrm{mg} / \mathrm{mouse}$ for cefbuperazone, latamoxef, cefotaxime, and $0.5 \mathrm{mg} /$ mouse for cefmetazole.

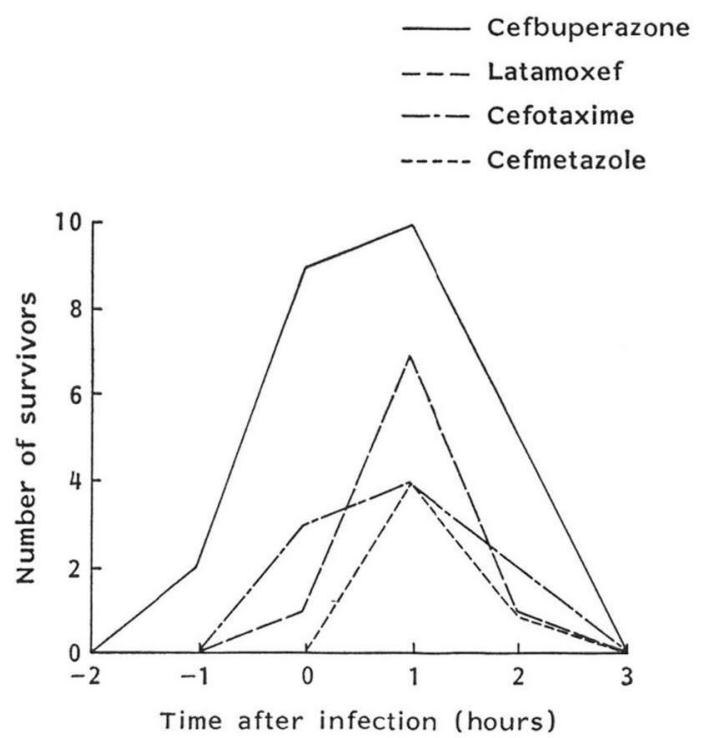

always lower than those of the other antibiotics regardless of administration time or challenged microbes. The MICs of cef buperazone, latamoxef, cefotaxime, and cefmetazole to E. coli ML4707 were $0.05,0.05,0.0125$, and $0.39 \mu \mathrm{g} / \mathrm{ml}$, respectively. Table 2 shows that each antibiotic was bactericidal at the MICs against the organisms used in the protection tests.

Although the MICs and MBCs of cefbuperazone were equal to those of latamoxef and 2 or 4 times higher than those of cefotaxime, cefbuperazone showed a higher activity than latamoxef and cefotaxime in the protection tests.

Thus, it may be noteworthy that cefbuperazone protects mice lethally infected with $E$. coli and $K$. pneumoniae even when administered 4 hours prior to the infection.

\section{Serum Levels of Cefbuperazone after Subcutaneous Injection}

Fig. 4 shows the serum levels of cefbuperazone and the reference antibiotics after single subcutaneous injection of 1 and $4 \mathrm{mg} / \mathrm{mouse}$.

Fig. 3. $E D_{50}$ values of cefbuperazone against intraperitoneal infections when administered before or after bacterial challenge.

Mice (19 $\pm 1 \mathrm{~g}, 10$ animals/group) were infected with test organisms in $0.5 \mathrm{ml}$ of saline. The antibiotics were administered subcutaneously once at the times indicated in the figure.

$\begin{array}{ll}\text { (A) E. coli KC-14. } & \text { (B) E. coli ML4707. }\end{array}$

Inoculum size: $1.0 \times 10^{7}$ $\mathrm{cfu} / \mathrm{mouse}$.

(A)

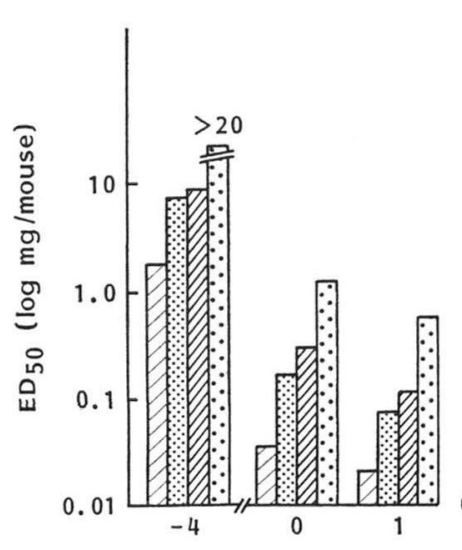

Inoculum size: $8.2 \times 10^{5}$ $\mathrm{cfu} /$ mouse.

(B)

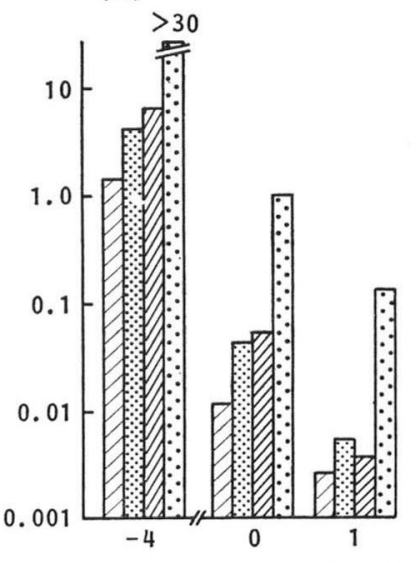

(C) $K$. pneumoniae $\mathrm{KC}-1$. Inoculum size: $3.9 \times 10^{3} \mathrm{cfu} /$ mouse.
(C)

Time after infection (hours)

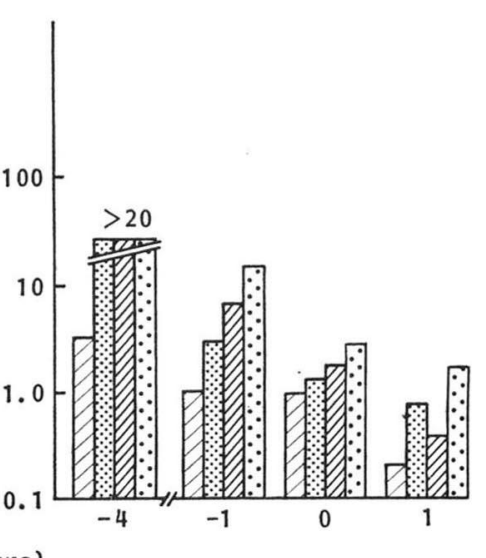

Cefbuperazone,

Latamoxef,

QD Cefotaxime,

Cefmetazole 
Table 2. MICs and MBCs of cefbuperazone against organisms used as challenge strains in mouse protection tests.

\begin{tabular}{lcccc}
\hline \multirow{2}{*}{ Organism } & \multicolumn{4}{c}{ Broth $\mathrm{MIC} / \mathrm{MBC}(\mu \mathrm{g} / \mathrm{ml})$} \\
\cline { 2 - 5 } & Cefbuperazone & Latamoxef & Cefotaxime & Cefmetazole \\
\hline E. coli KC-14 & $0.1 / 0.1$ & $0.1 / 0.1$ & $0.05 / 0.05$ & $0.78 / 0.78$ \\
E. coli ML4707 & $0.1 / 0.1$ & $0.1 / 0.1$ & $0.025 / 0.025$ & $0.39 / 0.39$ \\
K. pneumoniae KC-1 & $0.2 / 0.2$ & $0.2 / 0.2$ & $0.05 / 0.05$ & $1.56 / 1.56$ \\
\hline
\end{tabular}

Inoculum size: $1.0 \times 10^{4} \mathrm{cfu} / \mathrm{ml}$.

Fig. 4. Serum levels of cefbuperazone in mice after a single subcutaneous injection of 1 ( $)$ ), or $4 \mathrm{mg} /$ mouse $(\bigcirc)$.

Each point represents mean of values obtained from 5 mice at 5, 15, 30 minutes and 1, 2, 3 hours after injection.

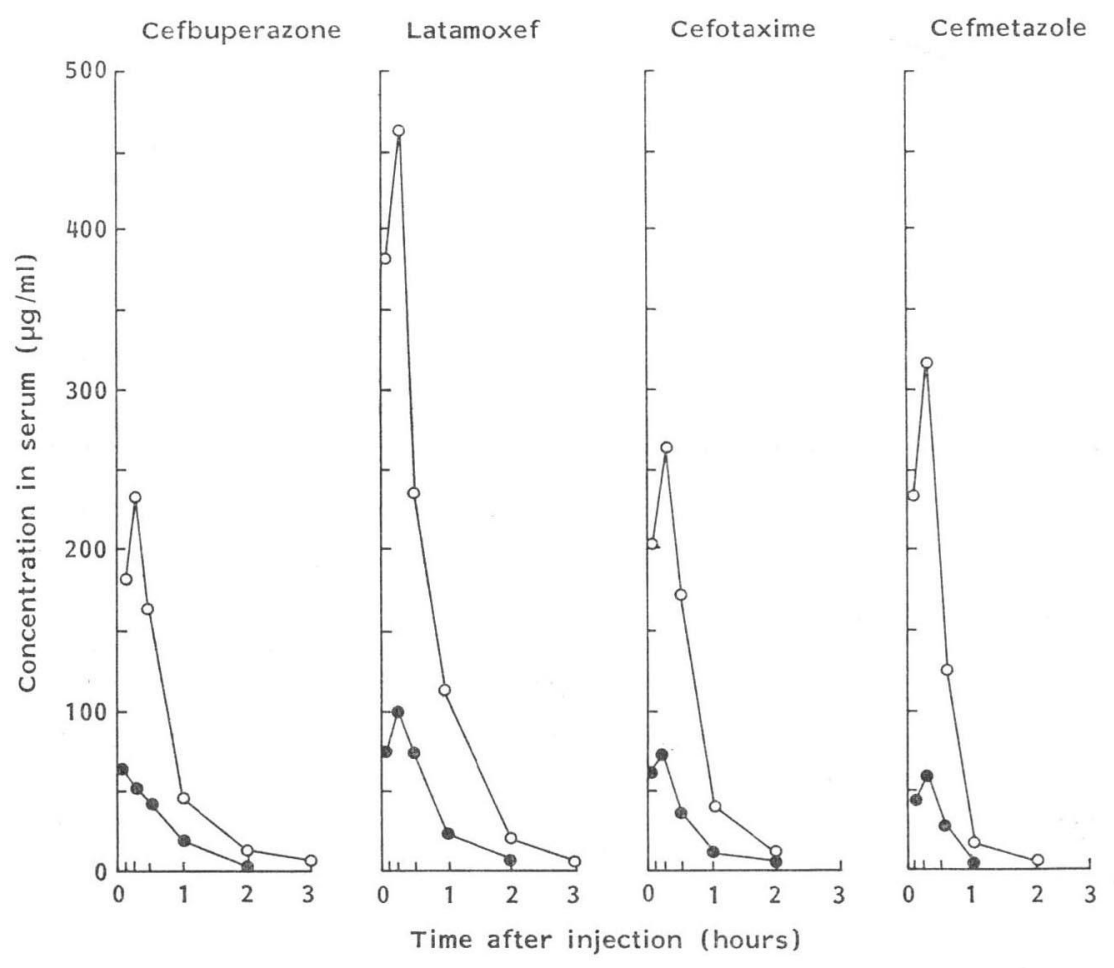

With $1 \mathrm{mg} /$ mouse, the peak serum levels of cefbuperazone, latamoxef, cefotaxime, and cefmetazole were $65.8,100,66.2$, and $55.3 \mu \mathrm{g} / \mathrm{ml}$, respectively. The measurable levels of cefbuperazone were more prolonged than those of cefmetazole and were similar to those of latamoxef and cefotaxime.

With $4 \mathrm{mg} /$ mouse, the peak values were (in $\mu \mathrm{g} / \mathrm{ml}$ ): cef buperazone 230; latamoxef 460 ; cefotaxime 265; cefmetazole 315 . The serum levels of cefbuperazone were more prolonged than those of cefotaxime and cefmetazole but were similar to those of latamoxef.

These findings indicate that comparatively high in vivo activity of cefbuperazone cannot be explained by differences in the serum levels.

Effect of Cefbuperazone on Experimental C. albicans Infection

The MICs of the tested antibiotics against C. albicans were confirmed to be more than $3,200 \mu \mathrm{g} / \mathrm{ml}$. 
Fig. 5. Survival curves of cef buperazone-treated mice in C. albicans infection.

Mice $\left(19 \pm 1 \mathrm{~g}, 10\right.$ animals/group) were intraperitoneally infected with $1.7 \times 10^{8} \mathrm{cfu} / \mathrm{mouse}$ of $C$. albicans in $0.5 \mathrm{ml}$ of saline. Each antibiotic was administered subcutaneously with 2 or $8 \mathrm{mg} / \mathrm{mouse}$ in a single dose 4 hours before (A), immediately after (B), and 1 hour after the infection (C).

(A) $2.0 \mathrm{mg} / \mathrm{mouse}$

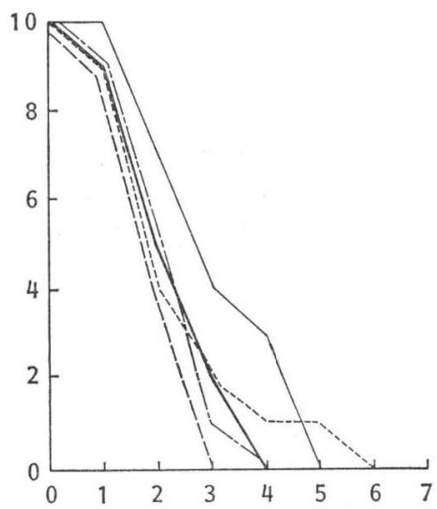

(B)

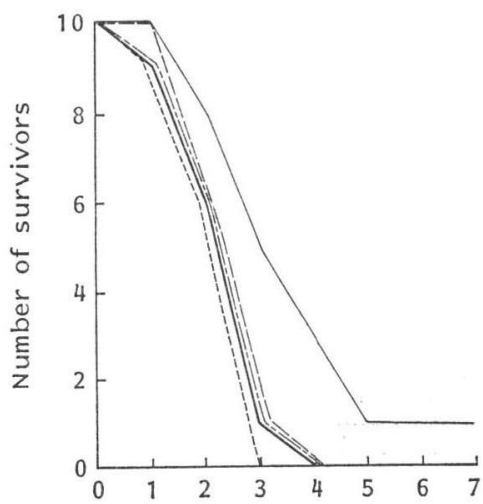

(C)

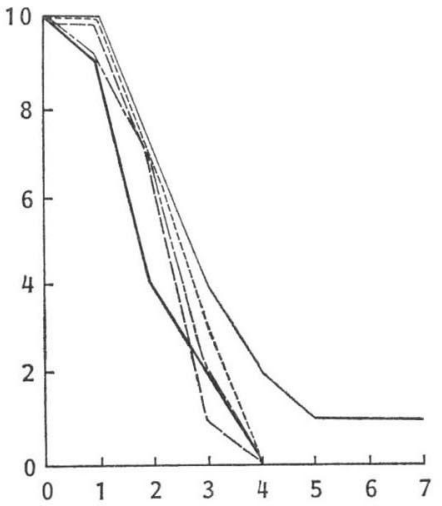

$8.0 \mathrm{mg} / \mathrm{mouse}$

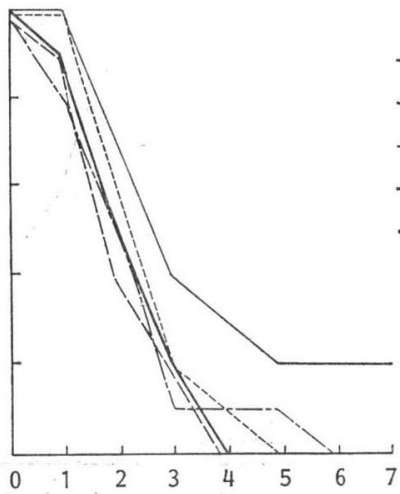

$8.0 \mathrm{mg} /$ mouse

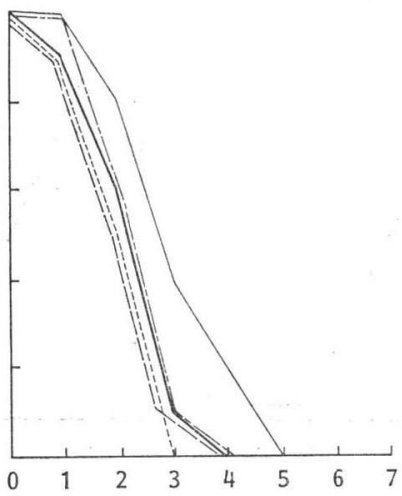

$8.0 \mathrm{mg} / \mathrm{mouse}$

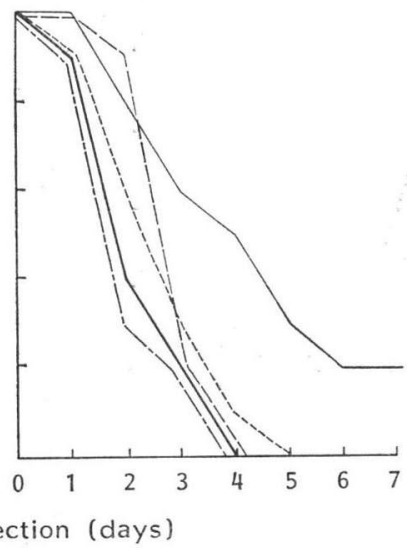

Cefbuperazone

Latamoxef

- - Cefotaxime

- - Cefmetazole

Control

Time after infection (days) 
Fig. 6. Effect of cefbuperazone on survival time of mice in C. albicans infection.

The survival rates of the control group and cefbuperazone-treated groups were calculated by the number of survivors pooled after the repeated experiments.

Inoculum size : $1.7 \times 10^{8} \mathrm{cfu} /$ mouse.

Treatment with cefbuperazone: 2 or $8 \mathrm{mg} / \mathrm{mouse}$ in a single dose 4 hours before (A), immediately after (B), and 1 hour after the infection (C).

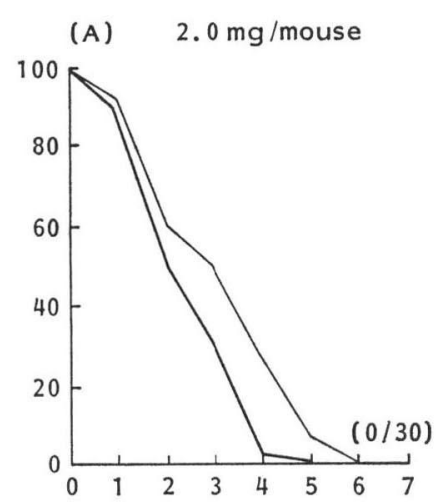

$8.0 \mathrm{mg} / \mathrm{mouse}$

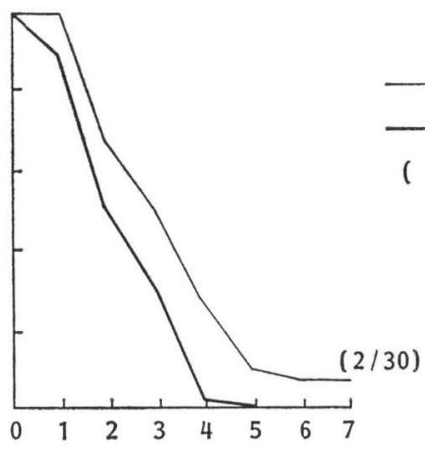

(B) $2.0 \mathrm{mg} / \mathrm{mouse}$

$8.0 \mathrm{mg} / \mathrm{mouse}$
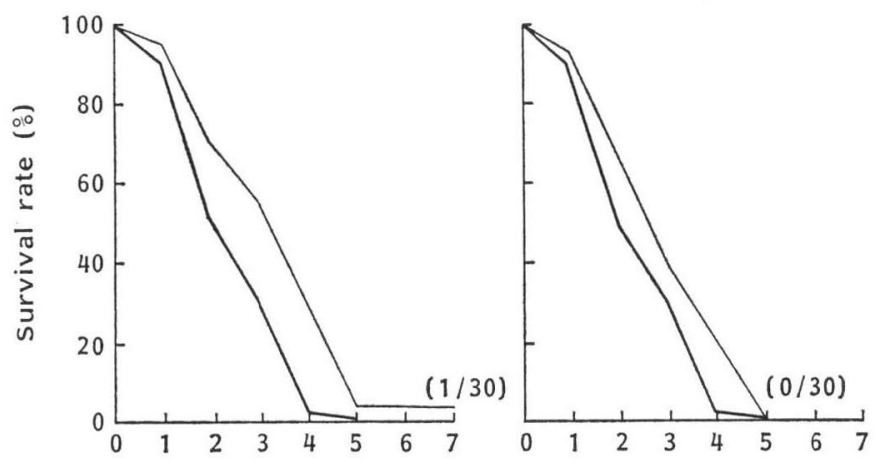

(c)

2.0. $\mathrm{mg} / \mathrm{mouse}$

$8.0 \mathrm{mg} / \mathrm{mouse}$

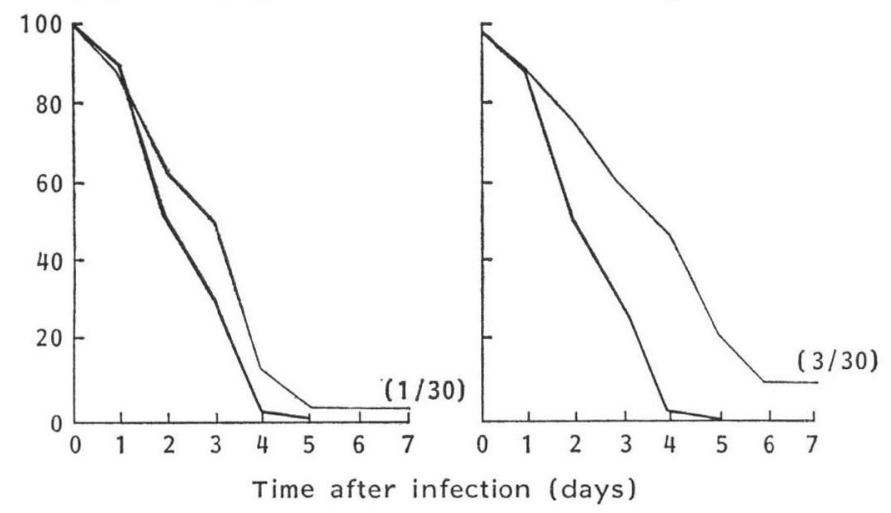

Mice were intraperitoneally infected with $1.7 \times 10^{8} \mathrm{cfu} / \mathrm{mouse}$ of the organism. Fig. 5 shows the survival curves of the control and groups treated with the antibiotics in single subcutaneous injection of 2.0 and $8.0 \mathrm{mg} / \mathrm{mouse}$.

All the control mice died within 5 days after the infection. Whereas, mice treated with 2.0 and 
Table 3. Statistical analysis of the prolonged survival time of cefbuperazone-treated mice in $C$. albicans infection.

\begin{tabular}{cccc}
\hline $\begin{array}{c}\text { Dose of } \\
\text { cef buperazone } \\
\text { (mg/mouse) }\end{array}$ & \multicolumn{3}{c}{ Treatment (hours after infection) } \\
\cline { 2 - 4 } & -4 & 0 & 1 \\
\hline 0.5 & $\mathrm{NS}$ & $\mathrm{NS}$ & $\mathrm{NS}$ \\
& $(\mathrm{n}=10)$ & $(\mathrm{n}=10)$ & $(\mathrm{n}=10)$ \\
2.0 & $P=0.0058^{* *}$ & $P=0.0007^{* * *}$ & $P=0.0418^{*}$ \\
& $(\mathrm{n}=30)$ & $(\mathrm{n}=30)$ & $(\mathrm{n}=30)$ \\
8.0 & $P=0.0020^{* *}$ & $P=0.0304^{*}$ & $P=0.000^{* * *}$ \\
& $(\mathrm{n}=30)$ & $(\mathrm{n}=30)$ & $(\mathrm{n}=30)$ \\
\hline
\end{tabular}

Significant differences from the control mice $(n=60)$ by the Cox-Mantel test.

NS: Not significant.

$8.0 \mathrm{mg} / \mathrm{mouse}$ of cefbuperazone manifested a prolongation of survival time as shown in the figure, but not when treated with the other reference antibiotics. With $0.5 \mathrm{mg} / \mathrm{mouse}$, no prolongation was observed in any antibiotic-treated group (data not shown). The experiments with the treatment given at 2.0 and $8.0 \mathrm{mg} / \mathrm{mouse}$ of cefbuperazone were repeated three times. As shown in Fig. 6 and Table 3 , the numbers of survivors were pooled, and analyzed statistically.

The survival time of cef buperazone-treated groups was longer than that of the control group whenever cefbuperazone was administered 4 hours before, immediately after, and 1 hour after the infection at doses equal to and greater than $2.0 \mathrm{mg} /$ mouse.

\section{Discussion}

Cefbuperazone has been reported to manifest a higher in vivo efficacy than other cephems showing the same in vitro activities ${ }^{2)}$. Its strong protection ability against intraperitoneal and urinary tract infections were confirmed in the present work, and could not be explained simply by the in vitro activity and serum levels. The pharmacokinetics of cefbuperazone have shown that its serum levels in mice are maintained similarly to or lower than those of latamoxef ${ }^{6)}$, in agreement with the results obtained in this study. Binding ratio to serum proteins in mice has been reported to be $35.4 \%$ for cefbuperazone and $53.9 \%$ for latamoxef ${ }^{8)}$. The low serum binding of cef buperazone may faborably affect the distribution of the antibiotic to the tissues and body fluids of mice, but the levels of cefbuperazone in the various tissues have been shown to be similar to those of latamoxef ${ }^{6)}$. Since cefbuperazone showed a comparatively high activity against experimental infections even when given 4 hours before bacterial challenge, its antibacterial activity appeared to be increased in vivo by synergy with the bactericidal effect of complement and/or macrophages, or by potentiating some other defense mechanism.

Leukocytes are known to play an important role in host defense against microbial infections ${ }^{7}$. Although many factors relating to host defense mechanisms have been investigated in vitro and in vivo, it is not clear whether in vitro tests reflect accurately the in vivo phenomenon. The mouse intraperitoneal infection model by $C$. albicans ${ }^{8)}$ was therefore employed to evaluate the stimulatory effect of antibiotic on the host defense mechanisms. Cefbuperazone prolonged the survival time of mice infected with $C$. albicans showing no sensitivity to $\beta$-lactams. This finding therefore suggests that the host defense mechanisms may be stimulated by cefbuperazone.

In conclusion, the good in vivo activity of cefbuperazone may depend on complex factors, i.e. pharmacokinetic properties such as serum binding, penetration into tissues and body fluids, and synergy with serum complement and macrophages, and/or some other stimulation of the host defense mechanisms.

\section{References}

1) Tai, M.; Y. Fukuoka, A. Yotsuit, K. Kumano, M. Takahashi, H. Mikami, T. Yasuda, I. Saikawa \& 
S. MrtsuHASHI: In vitro and in vivo antibacterial activity of T-1982, a new semisynthetic cephamycin. Antimicrob. Agents Chemother. 22: 728 734, 1982

2) Kumano, K.; H. Mikami, M. Inoue \& S. Mitsuhashi: In vitro and in vivo antibacterial activity of T1982. Chemotherapy (Tokyo) 30(S-3): $1 \sim 19,1982$

3) Minami, S.; N. Matsubara, A. Yotsuji, H. Araki, Y. Watanabe, T. Yasuda, I. Saikawa \& S. MitsuHASHI: Inactivation of cephamycins by various $\beta$-lactamases from Gram-negative bacteria. J. Antibiotics 37: $577 \sim 587,1984$

4) Sekiguchi, R. \& T. Yokota: Synergy of bactericidal effect of T-1982 with the serum complement and cultured macrophages. Abstr. 22nd Intersci. Conf. Antimicrob. Agents Chemother., No. 628, Miami Beach, 1982

5) Nishi, T. \& K. Tsuchiya: Experimental urinary tract infection with Pseudomonas aeruginosa in mice. Infect. Immun. 22: 508 515, 1978

6) Saikawa, I.; T. Yasuda, Y. Watanabe, T. Hayashi, S. Minami, K. Kumano, H. Araki \& K. MatsuNAGA: Absorption, distribution, biotransformation and excretion of T-1982. Chemotherapy (Tokyo) 30(S-3): $145 \sim 157,1982$

7) Tatsukawa, K.; M. Mrtsuyama, K. Takeya \& K. Nomoto: Differing contribution of polymorphonuclear cells and macrophages to protection of mice against Listeria monocytogenes and Pseudomonas aeruginosa. J. Gen. Microbiol. 115: 161 165, 1979

8) Yокота, T.; K. Nogaki, H. Ogawa \& T. Akiba: Stimulatory effect of the streptococcal preparation picibanil on phagocytosis. Current Chemotherapy, Proceedings of the 10th International Congress of Chemotherapy, Vol. I. pp. $324 \sim 326$, Am. Soc. Microbiol., Washington D.C., 1978 